\title{
THE DETERIORATION OF COMPLEMENT ACTIVITY IN NORMAL HUMAN SERUM ${ }^{1}$
}

\author{
By ARNOLD W. POHL AND DAVID D. RUTSTEIN \\ (From The Pneumonia Service, Department of Medicine, Albany Medical College, and the Bureau \\ of Pneumonia Control, New York State Department of Health, Albany, New York)
}

(Received for publication July 6, 1943)

In a previous paper (1), normal standards of hemolytic complement activity of normal human serum were established by an accurate quantitative technique (2) and striking decreases were reported occurring during pneumococcus pneumonia, during serum sickness, and after intravenous type-specific antipneumococcus serum, but not after intravenous sulfonamide administration. The complement titrations were, in the majority of cases, performed within $\mathbf{4 8}$ hours of the time that the blood was collected, although a few specimens were titrated as long as $\mathbf{7 2}$ hours after collection.

Probably because of its importance in many laboratory tests, the deterioration of complement activity of guinea pig serum has been more intensively studied than has that of humans. NattanLarrier and Grimard (3) studied the rate of deterioration of guinea pig complement activity at $5^{\circ} \mathrm{C}$., using 100 per cent hemolysis as the endpoint. They found that the complement activity disappeared in 25 per cent of the specimens kept from 9 to 15 days. Pierret and Breton (4) found that guinea pig serum kept on ice lost 60 per cent of its complement-fixation power in 8 days and 90 per cent in 15 days. Norton, Barfield, and Falk (5), using guinea pig, rabbit, and swine serums, found that complement activity according to Kolmer's technique deteriorated rapidly at $37^{\circ} \mathrm{C}$., activity disappearing within 3 days; while at 4 to $6^{\circ} \mathrm{C}$., the original activity was retained for 48 hours, and in 7 days, the unit was 2 to 3 times as much as that of fresh serum. Bigger (6), using guinea pig serum, stated that 75 per cent loss of complement activity occurs in 87 hours at $20^{\circ} \mathrm{C}$., whereas an equal loss is not noted before 165 hours at $9^{\circ} \mathrm{C}$. The method used was Dreyer's modification of Jorgenson and Madsen's technique, where one

\footnotetext{
1 This study was aided in part by a grant from the John and Mary R. Markle Foundation.
}

unit of complement activity is that amount which will cause 60 per cent hemolysis of a sensitized sheep cell suspension. Williamson (7) stated that serum centrifuged to perfect clearness loses one-third of its complement activity in $\mathbf{5}$ days at ice-box temperature. It is evident that different techniques, at varying temperatures, make it impossible to compare these results.

A similar situation exists, with fewer available data, concerning the rate of deterioration of complement activity in human serum. NattanLarrier and Grimard (3) showed that the complement activity of human serum at $5^{\circ} \mathrm{C}$. disappeared, in 70 per cent of the cases, after 9 to 15 days. They further observed that complement activity was absent in $\mathbf{4 1}$ per cent of human sera kept for 4 days. Bergenhem (8) cites Massol and Grysez to the effect that human serum loses its complement activity after one-half hour at $37^{\circ} \mathrm{C}$., while it is characteristic of complement activity that at $20^{\circ} \mathrm{C}$. or under, a relatively long time is necessary until it completely disappears.

In the light of these varying reports, it seemed desirable to study further the normal limits and the progressive deterioration of hemolytic complement activity in specimens of human blood serum, by an accurate quantitative technique (2), at temperatures to which blood specimens are commonly exposed, i.e., refrigerator temperature $\left(6^{\circ} \mathrm{C}\right.$.) and room temperature $\left(23^{\circ}\right.$ to $25^{\circ} \mathrm{C}$.).

\section{MATERIALS AND METHODS}

Complement activity was estimated in the blood serum of 71 normal individuals of both sexes. Blood specimens were collected by venepuncture and allowed to clot, centrifuged, and the serum pipetted into sterile, dry tubes which were tightly corked when not in use.

Titrations were determined by the technique of Wadsworth, Maltaner, and Maltaner (2). Briefly, the main points in this technique are as follows: A series of tubes containing sensitized sheep red cells, plus varying dilutions of the serum to be tested, are placed for 15 minutes in a 
water bath, kept at $37^{\circ} \mathrm{C}$. The amount of hemolysis in each tube is determined by comparison with carefully prepared standards and then plotted on a logarithmic scale. A straight line can then be drawn through these points to determine the hemolytic complement activity. The endpoint in this standardized system is that amount of serum which is required to produce 50 per cent hemolysis. The advantages of this method over those dependent upon the choice of the one tube in which hemolysis begins or ends have been reported by Wadsworth, Maltaner, and Maltaner (2).

Complement activity is reported in this study in terms of the volume of blood serum in milliliters required to produce 50 per cent hemolysis. Since the volume required is inversely related to the complement activity, the larger the number of milliliters indicated, the lower the complement activity in the specimen of blood serum, and vice versa.

\section{NORMAL COMPLEMENT ACTIVITY}

The complement activity in the blood serum of 71 apparently healthy individuals has statistically a "normal" distribution as shown in Table I.

No specimen had an index of activity lower than $0.0066 \mathrm{ml}$. or greater than $0.0028 \mathrm{ml}$. The great majority of the serums had a complement activity between 0.0040 and $0.0059 \mathrm{ml}$. The median was $0.0049 \mathrm{ml}$.

Specimens of blood serum of 62 persons, whose ages were known, were grouped according to age, as in Table II. The ages ranged from 10 to 84 years and the differences in the medians for each group are not significant. Table III shows the grouping of the indices of complement activity of specimens of blood serum of the same 62 persons according to sex and no significant differences were noted. The findings with respect to age and sex are consistent with those reported

TABLE I

Distribution of complement activity* of the serum of normal individuals

\begin{tabular}{ccc}
\hline \hline Volume of serum* & Normal persons & Median \\
\hline ml. & & $m l$. \\
0.0020 to 0.0029 & 1 & \\
0.0030 to 0.0039 & 7 & \\
0.0040 to 0.0049 & 28 & \\
0.0050 to 0.0059 & 27 & \\
0.0060 to 0.0070 & 8 & 0.0049 \\
Total & 71 & \\
\hline
\end{tabular}

* Complement activity is inversely related to the volume of serum required to produce 50 per cent hemolysis in a standardized system. Therefore, an increase in volume indicates a decrease in complement activity, and a decrease in volume indicates an increase in complement activity.
TABLE II

Complement activity* of the serum of normal individuals grouped according to age

\begin{tabular}{c|c|c|c}
\hline \hline \multirow{2}{*}{ Age } & $\begin{array}{c}\text { Number } \\
\text { of } \\
\text { cases }\end{array}$ & \multicolumn{2}{|c}{ Volume of serum* } \\
\cline { 2 - 4 } & & Range & Median \\
\hline years & & \multicolumn{3}{|c}{ ml. } \\
10 to 29 & 30 & 0.0033 to 0.0063 & 0.0049 \\
30 to 49 & 22 & 0.0037 to 0.0065 & 0.0045 \\
Over 50 & 10 & 0.0044 to 0.0058 & 0.0052 \\
\hline
\end{tabular}

* See note under Table I.

by Meisel and Wasilkowska-Krukowska (9), where the unit used was the smallest amount of blood serum causing the first trace of hemolysis.

Specimens from 41 cases, the total for which the information was available, were grouped according to the number of days between the collection of the specimen and the test for complement activity. Between the time of collection and the time of testing, the specimens were refrigerated at $6^{\circ} \mathrm{C}$. Seventeen specimens were tested on the same day they were collected; 18 specimens, 1 day after; and 6 specimens, 2 days after collection. The variations in the median complement activity (Table IV) of these groups of blood serums, kept at $6^{\circ} \mathrm{C}$., tested at different intervals following collection, are not significant. Moreover, these changes were insignificant when compared to the relatively large decreases in complement activity occurring during pneumonia, during serum sickness, and when typespecific antipneumococcus horse and rabbit serums were administered intravenously to pneumonia patients (1).

\section{DETERIORATION OF COMPLEMENT ACTIVITY AT REFRIGERATOR AND ROOM TEMPERATURE}

The blood serum of each of 17 normal individuals was divided into 2 portions, one of which was kept at $6^{\circ} \mathrm{C}$. and the other at 23 to $25^{\circ} \mathrm{C}$. Tests were done at intervals until the complement activity was well below the normal range (over $0.0066 \mathrm{ml}$.). The general trends of the progressive deterioration of complement activity are charted in Table V, where, for the sake of clarity and brevity, only the median values are shown. The median complement activity of blood serum stored at $6^{\circ} \mathrm{C}$. is reduced below the 
lower limit of normal within 11 to 13 days; whereas at 23 to $25^{\circ} \mathrm{C}$., it requires only 2 days to be reduced to the same extent.

Table $\mathrm{V}$ also shows the median percentage decrease in complement activity after storage at room and refrigerator temperature. The decrease in activity progresses with time. Thus, after 2 days at room temperature, median complement activity is reduced 46 per cent, while at refrigerator temperature, it is reduced 44 per cent in the interval of 11 to 13 days; and on the fourth day at room temperature, the median complement activity is reduced more than 117 per cent whereas 14 to 17 days at refrigerator temperature are required for similar reduction in activity.

TABLE III

Complement activity* of the serum of normal individuals grouped according to sex

\begin{tabular}{l|c|c|c}
\hline \multirow{2}{*}{ Sex } & \multirow{2}{*}{$\begin{array}{c}\text { Number } \\
\text { of } \\
\text { cases }\end{array}$} & \multicolumn{3}{|c}{ Volume of serum* } \\
\cline { 2 - 4 } & & \multicolumn{3}{|c}{ Range } & Median \\
\hline & 46 & 0.0033 to 0.0065 & 0.0050 \\
Males & 46 & 0.0039 to 0.0060 & 0.0047 \\
\hline
\end{tabular}

* See note under Table I.

Complement activity of individual specimens of blood serum decreased to below the normal range (over $0.0066 \mathrm{ml}$.) at refrigerator temperature $\left(6^{\circ} \mathrm{C}\right.$.) on the following days: 2 on the second, 6 on the seventh, 3 on the 11th to 13th, and 6 on the 14th to 17 th. At room temperature (23 to $25^{\circ} \mathrm{C}$.), the complement activity dropped to similar levels on the following days: 1 on the first, 5 on the second, 2 on the third, 3 on the

TABLE IV

Complement activity* of the serum of normal individuals grouped according to the number of days between collection of the specimen and testing

\begin{tabular}{c|c|c|c}
\hline \hline \multirow{2}{*}{ Days } & $\begin{array}{c}\text { Number } \\
\text { of } \\
\text { cases }\end{array}$ & \multicolumn{2}{|c}{ Volume of serum* } \\
\cline { 3 - 4 } & & \multicolumn{3}{|c}{ Range } & Median \\
\hline & & \multicolumn{3}{|c}{ ml. } \\
0 & 17 & 0.0039 to 0.0061 & 0.0049 \\
1 & 18 & 0.0036 to 0.0066 & 0.0045 \\
2 & 6 & 0.0028 to 0.0065 & 0.0052 \\
\hline
\end{tabular}

* See note under Table I.
TABLE V

Complement activity* of blood serum of 17 normal individuals according to the number of days of storage and its rate of deterioration at refrigerator $\left(6^{\circ} C\right.$.) and room temperatures $\left(23\right.$ to $25^{\circ} \mathrm{C}$.)

\begin{tabular}{|c|c|c|c|c|}
\hline \multirow{2}{*}{$\begin{array}{l}\text { Days } \\
\text { of } \\
\text { storage }\end{array}$} & \multicolumn{2}{|c|}{ Median volume of serum* } & \multicolumn{2}{|c|}{ Increase in median volume } \\
\hline & $6^{\circ} \mathrm{C}$ & 23 to $25^{\circ} \mathrm{C}$. & $6^{\circ} \mathrm{C}$. & 23 to $25^{\circ} \mathrm{C}$. \\
\hline $\begin{array}{c}0 \\
1 \\
2 \\
3 \\
4 \\
5 \\
6 \text { to } 7 \\
8 \text { to } 10 \\
11 \text { to } 13 \\
14 \text { to } 17\end{array}$ & $\begin{array}{l}0.0046 \\
0.0050 \\
\\
0.0053 \\
0.0054 \\
0.0064 \\
0.0064 \\
0.0066 \\
0.01\end{array}$ & $\begin{array}{ll} & \\
0.0046 \\
0.0052 \\
0.0067 \\
0.0081 \\
0.01\end{array}$ & $\begin{array}{r}8.7 \\
15.2 \\
17.4 \\
39.1 \\
39.1 \\
43.5 \\
>117.4\end{array}$ & \begin{tabular}{|l} 
cent \\
\\
13.0 \\
45.7 \\
76.1 \\
$>117.4$
\end{tabular} \\
\hline
\end{tabular}

* See note under Table I.

fourth, 4 on the fifth, and 1 on the seventh day. It is to be noted that the lowest level of the normal range still represents a significant quantity of complement activity. If an arbitrary point such as $0.01 \mathrm{cc}$. is selected, where most of the complement activity has disappeared, the changes in individual specimens fall into a somewhat different pattern. At refrigerator temperature $\left(6^{\circ} \mathrm{C}\right.$.), complement activity reached this arbitrary level on the following number of days: 1 on the third, 3 on the sixth to seventh, 3 on the 8 th to 10 th, 2 on the 11 th to 13 th, and 8 on the 14 th to 17 th. At room temperature (23 to $25^{\circ} \mathrm{C}$.), complement activity reached the same arbitrary level on the following number of days: 2 on the third, 4 on the fourth, 8 on the fifth, 2 on the sixth to seventh, and 1 on the eighth.

\section{CONCLUSIONS}

1. In normal individuals, the median amount of human blood serum required to produce 50 per cent hemolysis of a standardized sheep red cell suspension is $0.0049 \mathrm{ml}$.

2. The median is not significantly changed by age, sex, or a 48 -hour delay, at $6^{\circ} \mathrm{C}$., between the time of collecting and of testing.

3. At refrigerator temperature $\left(6^{\circ} \mathrm{C}\right.$.), the median complement activity of specimens of human serum is reduced beyond the lower limits of normal in 11 to 13 days. The median percentage decrease in this time interval is 44 per 
cent. At room temperature $\left(23\right.$ to $25^{\circ} \mathrm{C}$.), there is a similar reduction in 2 days.

We wish to acknowledge the cooperation and advice extended to us by Dr. Frank Maltaner of the Division of Laboratories and Research of the New York State Department of Health.

\section{BIBLIOGRAPHY}

1. Rutstein, D. D., and Walker, W. H., Complement activity in pneumonia. J. Clin. Invest., 1942, 21, 347.

2. Wadsworth, A., Maltaner, E., and Maltaner, F., Quantitative determination of fixation of complement by immune serum and antigen. J. Immunol., 1931, 21, 313.

3. Nattan-Larrier, L., and Grimard, L., Action du vieillissement sur l'alexine du sérum humain. Compt. rend. Soc. de biol., 1937, 125, 512.

4. Pierret, R., and Breton, A., The alexins of serum kept on ice. Compt. rend. Soc. de biol., 1926, 93, 1612. Abst. J. A. M. A., 1926, 86, 987.

5. Norton, J. F., Barfield, B., and Falk, I. S., Complement degeneration on storage at several temperatures. J. Infect. Dis., 1927, 41, 39.

6. Bigger, J. W., The loss of complementing power in guinea pig serum at various temperatures. J. Path. and Bact., 1919, $22,323$.

7. Williamson, N. E., Clarification of complement in relation to its preservation. J. Lab. and Clin. Med., 1917, 2, 518.

8. Bergenhem, B., Experimentelle Untersuchungen über die spontanen Veränderungen des Blutes in vitro hinsichtlich Suspensionsstabilität, Komplementaktivität, und Antithrombinfunktion. Acta path. et microbiol. Scandinav., 1939, supp. 39, 1.

9. Meisel, H., and Wasilkowska-Krukowska, H., Factors influencing amount of complement and hemolytic amboceptor in human serum. Polska gaz. lek., 1934, 13, 435. 